\title{
Sample Preparation for N-Glycosylation Analysis of Therapeutic Monoclonal Antibodies by Electrophoresis
}

\author{
Ákos Szekrényes, Jan Partyka, Csaba Varadi, Jana Krenkova, \\ Frantisek Foret, and András Guttman
}

\begin{abstract}
There are a considerable number of biopharmaceuticals that have been approved for clinical use in the past decade. Over half of these new generation drugs are glycoproteins, such as monoclonal antibodies or other recombinant glycoproteins, which are mostly produced in mammalian cell lines. The linked carbohydrate moieties affect not only their physicochemical properties and thermal stability but also crucial features like receptor-binding activity, circulating half-life, as well as immunogenicity. The structural diversity of these attached glycans can be manifested in altered monosaccharide composition and linkages/positions among the monosaccharide building blocks. In addition, as more and more biosimilar products hit the market, understanding the effects of their glycosylation modification has become a recent target in efficacy and safety issues. To ensure consistent quality of these products, glycosylation profiles have to be monitored and controlled in all steps of the manufacturing process, i.e., from clone selection to lot release. In this paper, we describe some of the recently introduced and commonly used sample preparation techniques for capillary electrophoresis $(\mathrm{CE})$-based profiling and structural elucidation of $\mathrm{N}$-glycans. The presented protocols include protein A affinity partitioning of monoclonal antibodies (mAbs), enzymatic release of the $\mathrm{N}$-linked glycans, labeling of the liberated carbohydrates, reaction mixture purification techniques to remove the excess labeling reagent, and high-resolution and rapid capillary electrophoresis-laser-induced fluorescence (CE-LIF)-based profiling of the labeled and purified $\mathrm{N}$-glycans.
\end{abstract}

Key words Biopharmaceuticals, Therapeutic monoclonal antibody, N-glycan analysis, Fluorophore labeling, Capillary electrophoresis

1 Introduction

Glycosylation is one of the most important and complex posttranslational modifications on the majority of new biotherapeutic drugs. Glycoproteins are typically produced as mixtures of different glycoforms having the same polypeptide backbone but differing in glycosylation site specificity (macroheterogeneity) and in the structures at a same site (microheterogeneity) [1]. It is well known that these attached carbohydrate chains are very important from the point of view of quality by design $(\mathrm{QbD})$ in biopharmaceutical 
manufacturing because of their significant influence on activity and efficacy. Since glycan biosynthesis and processing are exquisitely responsive to the host cell type and growth environment, changes may occur in the glycosylation profile of different production batches of the innovative drug but also in their follow-up versions (biosimilars) [2]. Meanwhile, there have been reports of adverse events caused by nonhuman glycosylation moieties due to the presence of immunogenic residues, such as $\alpha-1,3-\mathrm{Gal}$ or $\mathrm{N}$-glycolylneuraminic acid [3]. Therefore, it is crucial to maintain the carbohydrate distribution profile of glycosylated biopharmaceuticals for efficient and safe use [4,5]. Advances are continually being made in the biotechnology industry to minimize glycan heterogeneity and improve the sensitivity and specificity of the analytical assays used to identify and quantify possible glycosylation changes. In spite of the fact that several analytical techniques and assays have already been implemented and validated for the characterization of these complex molecules, rapid and comprehensive profiling and quantitation of all glycoforms are still a challenging task. One of the most powerful bioseparation techniques for detailed N-linked glycosylation analysis of biotherapeutics is capillary electrophoresis combined with laser-induced fluorescent (CE-LIF) detection [6-10]. Different CE-based assays can be used to characterize the drug during the manufacturing process, troubleshoot production problems, and demonstrate biosimilarity or comparability.

In this protocol, we introduce some of the most efficient sample preparation methods for CE-LIF analysis of complex carbohydrates. Usual protocols start with affinity partitioning of the formulated or crude monoclonal antibody product using protein $\mathrm{A}$ resins. This step is essential for the complete removal of all additives and formulation ingredients, which can affect glycan labeling or the consequent CE-LIF analysis. Next, we describe some of the commonly used in-solution $\mathrm{N}$-glycan release method using peptide-N-glycosidase $\mathrm{F}$ (PNGase $\mathrm{F}$ ). The affinity partitioning and glycan release steps are followed by fluorophore labeling of the liberated glycans and the removal of the excess labeling material. Finally, we describe the optimal capillary electrophoresis analysis parameters for the labeled $\mathrm{N}$-linked glycans in respect to regular profiling (high resolution) and rapid screening (low resolution).

\section{Materials}

Always use HPLC grade or ultrapure water $\left(18 \mathrm{M} \Omega \mathrm{cm}\right.$ at $\left.25^{\circ} \mathrm{C}\right)$ for all solutions and buffers in all procedures. In addition, all reagents should be microbiology or HPLC grade unless otherwise stated. The use of powder-free, nitrile gloves for all sample handling procedures is important too. Ensure that all glass, plasticware, 
and solvents are free of glycosidases and possible environmental carbohydrate contaminations. All procedures should be performed using appropriate personal safety protection, laboratory coat, eyeglasses, and nitrile gloves. The labeling reactions should be performed in a fume hood.

2.1 Protein A Affinity Partitioning Using PhyTip 200+ Columns
1. Crude or formulated mAb sample.

2. $1 \times$ PBS buffer, $\mathrm{pH} 7.2$.

3. 200+ PhyTip protein A columns with $5 \mu \mathrm{L}$ bed volume (Phynexus Inc., San Jose, CA).

All PhyTip protein A columns are supplied with buffers and reagents including:

Capture buffer: provided for those situations where additional buffer is needed to supplement sample volume and ensure correct capture $\mathrm{pH}$.

Wash buffer I: phosphate buffer solution, $\mathrm{pH} 7.4$.

Wash buffer II: saline solution.

Envichment buffer: phosphate buffer solution, $\mathrm{pH} 2.5$.

Neutralization buffer: Tris buffer solution, pH 9.0.

4. Rainin PureSpeed (Rainin Instrument LLC, Oakland, CA, USA) electronic semiautomated multichannel pipette ( 8 or 12 channels).

5. 96-well plate, $0.5 \mathrm{~mL} /$ well capacity.

6. 0.2-mL flat cap PCR tubes.

7. $100 \mathrm{mM}$ sodium carbonate buffer $(\mathrm{pH} 9.0)$ to replace the neutralization buffer.

8. $20 \mathrm{mM}$ sodium carbonate buffer, $\mathrm{pH}$ 7.0.

9. $10 \%$ acetic acid in water to replace the enrichment buffer.

10. $10 \mathrm{kDa}$ cutoff spin filters (Nanosep 10k Omega, Pall, Port Washington, NY, USA).

11. Microcentrifuge equipped with a rotor suitable for $2.0-\mathrm{mL}$ microfuge tubes and capable to provide $17,200 \times g$.

12. Centrifugal vacuum evaporator (e.g., SpeedVac).

\subsection{In-Solution \\ N-Glycan Release and APTS Labeling of $\mathrm{N}$-Glycans}

1. $50 \mathrm{mM}$ dithiothreitol (DTT) in water.

2. $50 \mathrm{mM}$ iodoacetamide (IAM) in water.

3. $20 \mathrm{mM} \mathrm{NaHCO}$, pH 7.0.

4. Peptide-N-glycosidase F (ProZyme, Hayward, CA, USA).

5. 0.2-mL flat cap PCR tubes.

6. PCR thermocycler or other general microvial-based heating devices capable to provide stable 65 and $37^{\circ} \mathrm{C}$ temperature.

7. $15 \%$ acetic acid in water. 


\subsection{APTS Cleanup
Using 1000+ PhyTip \\ 2.3 APTS Cleanup
Using 1000+ PhyTip with $20 \mu L$ Normal Phase Resin}

\subsection{Sample Preparation Using GlykoPrep Rapid N-Glycan Preparation Platform}

8. 8-Aminopyrene-1,3,6-trisulfonic acid (APTS) (Beckman Coulter, Brea, CA, USA).

9. $1 \mathrm{M}$ sodium cyanoborohydride in tetrahydrofuran (THF).

10. $10 \mathrm{mg} / \mathrm{mL}$ APTS solution in $15 \%$ acetic acid.

11. $10 \mathrm{kDa}$ cutoff spin filters (Nanosep $10 \mathrm{k}$ Omega, Pall, Port Washington, NY, USA).

12. Microcentrifuge equipped with a rotor suitable for $2.0-\mathrm{mL}$ microfuge tubes and capable to provide $17,200 \times g$.

13. Centrifugal vacuum evaporator.

14. Vortex mixer.

15. Pipettors and disposable pipette tips (P5/P10, P200, and P1000).

16. Miscellaneous labware for buffers and dilutions.

1. 1000+ PhyTip normal phase columns with $20 \mu \mathrm{L}$ bed volume.

2. Rainin multichannel $100-1000-\mu \mathrm{L}$ pipettor (8 channels).

3. Acetonitrile (100\%, HPLC grade).

4. $20 \%$ acetonitrile in water.

5. $95 \%$ acetonitrile in water.

6. 96-deep-well plate $2 \mathrm{~mL} /$ well.

7. Centrifugal vacuum evaporator.

8. 0.2-mL flat cap PCR tubes.

1. GlykoPrep Digestion Module (ProZyme) includes:

- Digestion ( $\mathrm{RX})$ cartridges (24 cartridges).

- Immobilization reagent set.

- Denaturation reagent.

- Blocking reagent.

- Digestion reagent set.

- N-Glycanase.

- $25 \times$ digestion buffer.

- Finishing reagent.

- Aluminum sealing film.

2. GlykoPrep APTS Cleanup Module (ProZyme) includes:

- $5 \times$ APTS sample loading buffer.

- Cleanup (CU) cartridges (24 cartridges).

3. Acetonitrile (HPLC grade).

4. Microcentrifuge (capable of $50-1,000 \times g$ ) and rotor suitable for $1.5-/ 2.0-\mathrm{mL}$ microcentrifuge vials.

5. Heater and heating block accommodating 0.2-mL PCR tubes.

6. Centrifugal vacuum evaporator. 
7. Vortex mixer.

8. Pipettors and disposable pipette tips (P5/P10, P200, and P1000).

9. Miscellaneous labware for buffers and dilutions.

\subsection{CE-LIF Analysis of APTS-Labeled N-Glycans}

1. Beckman Coulter PA 800 plus Pharmaceutical Analysis System, equipped with LIF detection (solid-state 488-nm laser) and 32 Karat software v.8.0 or higher.

2. Carbohydrate separation buffer (Beckman Coulter).

3. N-CHO-coated capillary, $50 \mu \mathrm{m}$ ID (Beckman Coulter).

4. Sample vials.

5. 2.0-mL plastic vials.

6. Vial caps.

7. Capillary cartridge equipped with $\mathrm{N}-\mathrm{CHO}$-coated capillary with a total length of $60.2 \mathrm{~cm}$ (effective length $50.2 \mathrm{~cm}$ ).

\section{Methods}

\subsection{Protein A Affinity Partitioning of mAbs}

1. Dilute the crude or formulated mAb sample to $2 \mathrm{mg} / \mathrm{mL}$ using the PBS buffer, pH 7.2 (see Note 1).

2. Transfer $220 \mu \mathrm{L}$ of capture buffer to the first row of the 96-well plate.

3. Transfer $100 \mu \mathrm{L}$ of diluted mAb sample and $120 \mu \mathrm{L}$ of capture buffer to each well in the second row. Mix the sample gently by pipetting.

4. Fill up the wells in the third row with $220 \mu \mathrm{L}$ of wash buffer I.

5. Fill up the wells in the fourth row with $220 \mu \mathrm{L}$ of wash buffer II.

6. Fill up the wells in the fifth row with $25 \mu \mathrm{L}$ of $10 \%$ acetic acid.

7. Conditioning (first row): $200 \mu \mathrm{L}$ of capture buffer over the resin bed for one cycle at a flow rate of $250 \mu \mathrm{L} / \mathrm{min}$.

8. Capture (second row): capture the IgG by passing $200 \mu \mathrm{L}$ of sample solution through the resin bed in four cycles at a flow rate of $100 \mu \mathrm{L} / \mathrm{min}$.

9. Purification (third and fourth row): pass $100 \mu \mathrm{L}$ of protein $\mathrm{A}$ wash buffer I through the resin bed in one cycle at a flow rate of $250 \mu \mathrm{L} / \mathrm{min}$ followed by a second wash with $200 \mu \mathrm{L}$ wash buffer II, passing through the resin bed in one cycle at a flow rate of $250 \mu \mathrm{L} / \mathrm{min}$. It is essential to use wash buffer II as it exchanges the $\mathrm{pH} 7.4$ buffer of wash buffer I and in doing so ensures effective low $\mathrm{pH}$ elution during the enrichment step.

10. Enrichment (fifth row): elute the captured IgG with $15 \mu \mathrm{L}$ $10 \%$ acetic acid solution $(\mathrm{pH} \sim 2.5)$ passed through the resin bed in four cycles at a flow rate of $100 \mu \mathrm{L} / \mathrm{min}$. Neutralize the sample by the addition of $175 \mu \mathrm{L}$ of $100 \mathrm{mM}$ sodium carbonate buffer ( $\mathrm{pH} 9.0)$. 


\subsection{In-Solution N-Glycan Release}

$3.3 \quad N-G l y c a n$ Release Using GlykoPrep Digestion (RX) Cartridges
11. Wash the membrane of the $10 \mathrm{kDa}$ cutoff spin filter with $250 \mu \mathrm{L}$ of water for $15 \mathrm{~min}$ at $17,200 \times \mathrm{g}$.

12. Pipette the sample onto the membrane and centrifuge for $15 \mathrm{~min}$ at $17,200 \times \mathfrak{g}$.

13. The sample is washed three times with $250 \mu \mathrm{L}$ of water by spinning for $15 \mathrm{~min}$ at $17,200 \times g($ see Note 2$)$.

14. The desalted proteins are recovered from the membrane by inversion of the cartridge-to a new tube-and centrifugation at $1,320 \times g$ for $4 \mathrm{~min}($ see Note 3$)$.

15. To increase the recovery, invert the cartridge again-back to the original position-pipette $50 \mu \mathrm{L}$ of water onto the membrane, vortex it for $1 \mathrm{~min}$, invert the cartridge, and centrifuge at $1,320 \times g$ for $4 \mathrm{~min}$. Repeat this step two times ( see Note 4).

16. After the desalting step, dry the recovered mAb sample in the centrifugal vacuum evaporator (heat setting turned to the off position) using continuous vacuum.

1. Dissolve the dry protein samples in $45 \mu \mathrm{L}$ of $20 \mathrm{mM}$ sodium carbonate buffer, $\mathrm{pH}$ 7.0.

2. Add $5 \mu \mathrm{L}$ of $50 \mathrm{mM}$ dithiothreitol (DTT) to the sample and incubate at $65^{\circ} \mathrm{C}$ for $15 \mathrm{~min}$.

3. After the incubation step, add $5 \mu \mathrm{L}$ of $50 \mathrm{mM}$ iodoacetamide (IAM) to the sample and keep in the dark for $10 \mathrm{~min}$ at room temperature $(\mathrm{RT})$.

4. Add $2 \mu \mathrm{L} 2.5 \mathrm{U} / \mathrm{mL}$ of $\mathrm{N}$-glycanase solution to the sample and incubate for $2 \mathrm{~h}$ to overnight at $37^{\circ} \mathrm{C}$.

5 . Wash the membrane of the $10 \mathrm{kDa}$ cutoff spin filter with $250 \mu \mathrm{L}$ of water for $15 \mathrm{~min}$ at $17,200 \times \mathfrak{g}$.

6. Pipette the sample onto the membrane and centrifuge for $15 \mathrm{~min}$ at $17,200 \times \mathrm{g}($ see Note 5$)$.

7. Wash the membrane again with $50 \mu \mathrm{L}$ of water for $15 \mathrm{~min}$ at $17,200 \times g$.

8. Collect the flow through and transfer it to a $0.2-\mathrm{mL}$ clean PCR tube.

9. Dry the clean released glycans in a centrifugal vacuum evaporator (heat setting turned to off position).

1. Dissolve the dry protein sample in $50 \mu \mathrm{L}$ of $20 \mathrm{mM}$ sodium carbonate buffer, $\mathrm{pH}$ 7.0.

2. Add $50 \mu \mathrm{L}$ of denaturation reagent to the protein solution. Mix well by pipetting up and down several times.

3. Incubate at room temperature for at least $5 \mathrm{~min}$.

4. Nest the cartridge in a $0.5-\mathrm{mL}$ screw cap microtube. 
5. Pipette $50 \mu \mathrm{L}$ of $100 \%$ acetonitrile into the sample cup of the RX cartridge.

6. Place the tube in a centrifuge and spin at $300 \times g$ for $3 \mathrm{~min}$.

7. Pipette $150 \mu \mathrm{L}$ of denaturation reagent into the sample cup of each cartridge.

8. Spin at $1,000 \times g$ for $2 \mathrm{~min}$.

9. Empty the flow through by lifting each RX cartridge and removing the liquid collected in the microtube below. Dispose off this liquid and return the cartridge to the tube.

10. Load $100 \mu \mathrm{L}$ of the denatured mAb sample into the sample cup of each RX cartridge.

11. Spin at $50 \times g$ until all sample cups are empty $(\sim 15 \mathrm{~min})$.

12. Empty the flow through as described in step 9.

13. Pipette $50 \mu \mathrm{L}$ of blocking reagent into the sample cup of each RX cartridge.

14. Spin at $300 \times g$ for $3 \mathrm{~min}$.

15. Pipette $50 \mu \mathrm{L}$ of digestion buffer $(1 \times$ concentrated $)$ into the sample cup of each RX cartridge.

16. Spin at $300 \times g$ for $3 \mathrm{~min}$.

17. Prepare the digestion and elution assembly by nesting each PCR tube into $0.5-\mathrm{mL}$ tubes and nesting that within a $2.0-\mathrm{mL}$ microcentrifuge tube.

18. Transfer the RX cartridge into the corresponding digestion and elution assemblies and return to the centrifuge. Dispose the microtubes and the flow through.

19. Pipette $10 \mu \mathrm{L}$ of enzyme solution $(2.5 \mu \mathrm{L}$ of $\mathrm{N}$-glycanase and $7.5 \mu \mathrm{L}$ of $\mathrm{l} \times$ digestion buffer) into the sample cup of the $\mathrm{RX}$ cartridge.

20. Spin at $300 \times g$ for $3 \mathrm{~min}$; do not discard the flow through.

21. Transfer the PCR tubes with the $\mathrm{RX}$ cartridges to a $45{ }^{\circ} \mathrm{C}$ PCR heat block and incubate for $30 \mathrm{~min}$.

22. Remove the PCR tubes with RX cartridges from the heat block and return to the digestion and elution assembly.

23. Pipette $15 \mu \mathrm{L}$ of finishing reagent into the sample cup of each RX cartridge.

24. Spin at $300 \times g$ for $3 \mathrm{~min}$.

25. Remove RX cartridge from the PCR tube. The eluted $\mathrm{N}$-glycans are now in the PCR tubes; do not discard.

26. Open the PCR tubes, return them to the digestion assembly (minus the RX cartridge), and dry the $\mathrm{N}$-glycans in a centrifugal vacuum evaporator (heat setting turned to the off position) for $30 \mathrm{~min}$ or until fully dry. 


\subsection{APTS Labeling of the Released N-Glycans}

\subsection{Removal of Excess APTS Using Normal Phase Columns}

1. Add $4 \mu \mathrm{L}$ of $10 \mathrm{mg} / \mathrm{mL}$ APTS (in $15 \%$ acetic acid) to the dried sugars.

2. Add $2 \mu \mathrm{L}$ of $1 \mathrm{M} \mathrm{NaBH}_{3} \mathrm{CN}$ (in THF) to the sample (see Note 6).

3 . Incubate the reaction mixture at $37{ }^{\circ} \mathrm{C}$ overnight. For nonsialylated glycoproteins, incubation at $55^{\circ} \mathrm{C}$ for $2 \mathrm{~h}$ is sufficient.

1. Add $100 \mu \mathrm{L}$ of water to the labeled samples and mix it by pipetting up and down several times. Transfer the mixture to the third row of the plate (Fig. 1) and add $900 \mu \mathrm{L}$ acetonitrile to it. Mix the sample well again.

2. Prepare the elution (20\% acetonitrile in water) and the washing solutions (95\% acetonitrile in water) and fill up the 96-deep-well plate as shown in Fig. 1 ( see Note 7).

3 . Insert the 1000+ DPA-6S normal phase PhyTip columns (20 $\mu \mathrm{L}$ bed volume) to the multichannel pipettor.

4. Perform conditioning in the first row (Fig. 1) by passing $900 \mu \mathrm{L}$ of elution solution through the resin bed four times.

5. Equilibrate the columns by passing $900 \mu \mathrm{L}$ of washing solution over the resin bed for four times in the second row in Fig. 1.

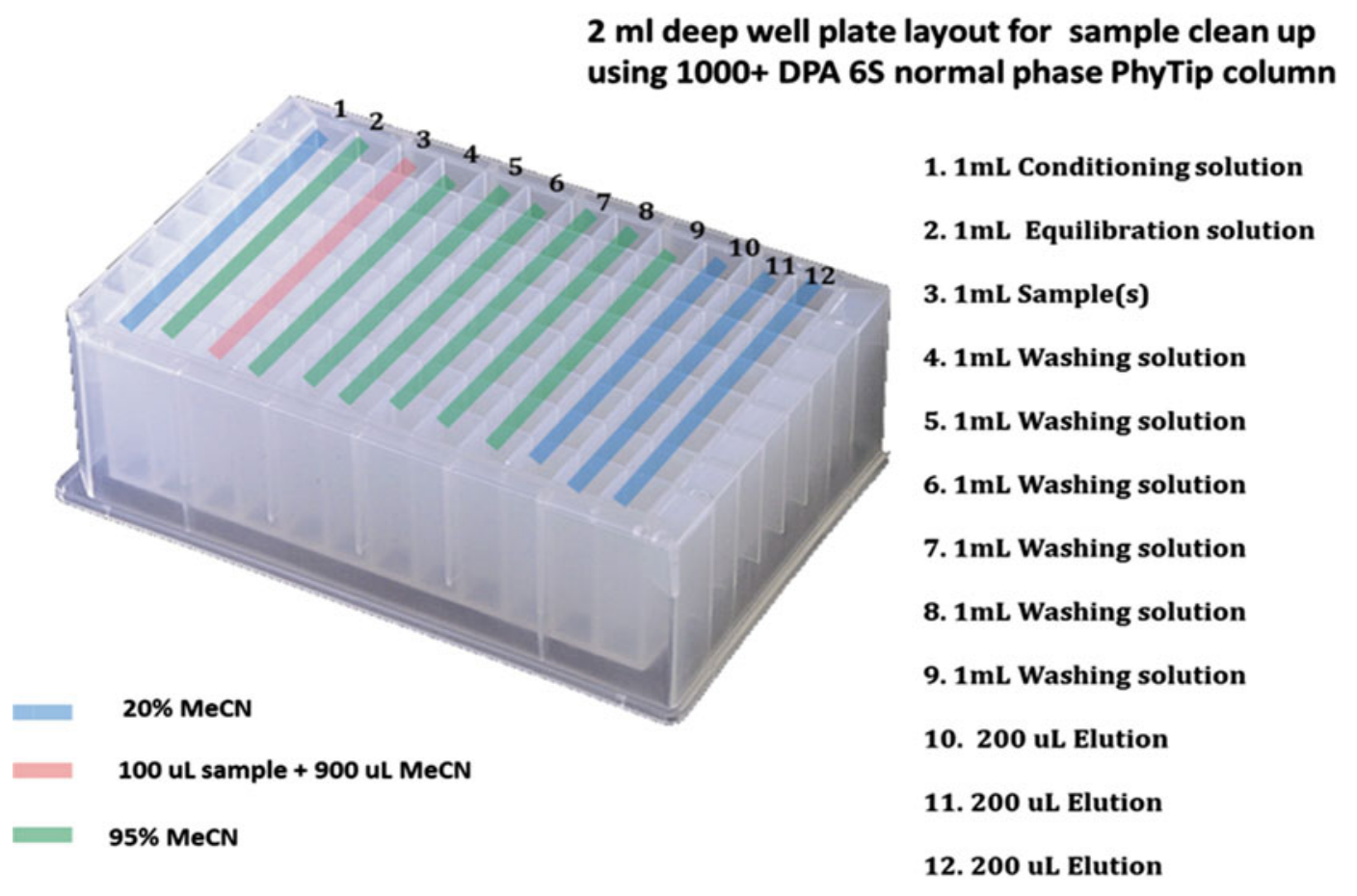

Fig. 1 Reagent distribution in a deep-well plate for labeling reagent cleanup 
6. Load the labeled glycans to the columns by pipetting $900 \mu \mathrm{L}$ of sample mixture through the resin bed ten times (Fig. 1, third row).

7. Wash off the salts and excess labeling reagent by pipetting $900 \mu \mathrm{L}$ of washing solution through the resin bed ten times. Repeat this step six times, always using fresh solution in a new row (Fig. 1, fourth to ninth row).

8. Elute the APTS-labeled glycans by passing $180 \mu \mathrm{L}$ elution solution through the resin bed three times. Repeat this step in the next two rows (Fig. 1, 10th to 12th row).

9. Collect the eluted sample from the elution positions to a 2.0$\mathrm{mL}$ tube and dry it in a centrifugal vacuum evaporator (heat setting turned to the off position).

10. Dissolve the dried samples in $25 \mu \mathrm{L}$ HPCE grade water and proceed to capillary electrophoresis analysis.

3.6 Cleanup of the FluorophoreLabeled Glycans by APTS Cleanup Modules
1. Prepare $5 \mathrm{~mL}$ of APTS sample load buffer by adding $1 \mathrm{~mL}$ of $5 \times$ APTS sample load buffer to a small, glass graduated cylinder. Bring the volume up to $5 \mathrm{~mL}$ with $100 \%$ acetonitrile.

2. Dissolve the dried and labeled glycan samples in $200 \mu \mathrm{L}$ of APTS sample load buffer. Pipette it up and down a couple of times to mix well.

3. Add $200 \mu \mathrm{L}$ of APTS sample load buffer to each $\mathrm{N}$-glycan sample in the PCR tubes. Pipette up and down to mix.

4. Transfer each $\mathrm{N}$-glycan sample into the sample cup of a CU cartridge. Place the CU cartridge into a $0.5-\mathrm{mL}$ tube by nesting within a $2.0-\mathrm{mL}$ microcentrifuge tube.

5. Spin at $300 \times g$ for 3 min or until the sample cup of each CU cartridge is empty.

6. Discard the flow through and spin at $300 \times g$ for $3 \mathrm{~min}$ again.

7. Pipette $200 \mu \mathrm{L}$ of APTS sample load buffer into the sample cup of each CU cartridge.

8. Spin at $300 \times g$ for $3 \mathrm{~min}$.

9. Discard the flow through and repeat steps 6 and 7 again.

10. Place the CU cartridge to a clean $0.2-\mathrm{mL}$ PCR tube and nest this back to the $2.0-\mathrm{mL}$ microcentrifuge tube, which is already containing the $0.5-\mathrm{mL}$ tube.

11. Pipette $25-50 \mu \mathrm{L}$ of ultrapure water into the sample cup of each CU cartridge.

12. Spin at $1,000 \times g$ for $3 \mathrm{~min}$. The PCR tube now contains the purified labeled N-glycans; do not discard.

13. N-Glycan samples are now ready for capillary electrophoresis analysis. If not analyzed immediately, store sealed at $-20^{\circ} \mathrm{C}$ in the dark. 


\subsection{CE-LIF Analysis of APTS-Labeled N-Glycans}

3.7.1 Preparing the Glucose Ladder Standard (G20)
3.7.2 Performing the High-Resolution CE-LIF Analysis
1. Weigh and dissolve $5 \mathrm{mg}$ of glucose ladder standard (G20, supplied with the $\mathrm{N}-\mathrm{CHO}$ Carbohydrate Kit) in $80 \mu \mathrm{L}$ deionized water in $1.5-\mathrm{mL}$ microcentrifuge tube. Sonicate if necessary.

2. Aliquot at least ten $2 \mu \mathrm{L}$ portions of the glucose ladder standard solution to $0.5-\mathrm{mL}$ microcentrifuge vials and dry them in a centrifugal vacuum evaporator. The dried glucose ladder can be stored at room temperature or used immediately.

3. Label the ladder standard as described under Subheading 3.4 and proceed with sample cleanup.

4. Transfer the APTS-labeled samples and standards to a $0.2-\mathrm{mL}$ sample tube (Beckman Coulter), nest the tubes to $2-\mathrm{mL}$ plastic vials, and cap them tight. Place the sample vials to the sample tray and record their actual positions in the methods timetable.

5. Fill the appropriate reagents into vials as follows:

- $1.5 \mathrm{~mL}$ of ultrapure water into $\mathrm{H} 2 \mathrm{O}$ vial (four vials).

- $1.5 \mathrm{~mL}$ of carbohydrate separation buffer into Gel-R vial (one vial).

- $\quad 1.3 \mathrm{~mL}$ of carbohydrate separation buffer into Gel-S vial (two vials).

- $\quad 0.8 \mathrm{~mL}$ of ultrapure water into waste vial (one vial).

Place the vials in the buffer tray and set up their actual positions in the methods timetable.

6. Set up the initial detection and separation parameters as follows:

- Detection: laser-induced fluorescence.

- Wavelength excitation, $488 \mathrm{~nm}$; emission, $520 \mathrm{~nm}$.

- Data rate: $4 \mathrm{~Hz}$.

- Dynamic range: 100 RFU (relative fluorescence units).

- Filter setting: normal.

- Peak width: 16-25.

1. Rinse the capillary with buffer for $3 \mathrm{~min}$ at $30 \mathrm{psi}$ from gel buffer (Gel-R vial for rinse) vial to waste vial.

2. Inject the sample at 0.5 psi for 5 s from sample vial to buffer vial (Gel-S vial for separation).

3. Wait for $0.2 \mathrm{~min}$ with vials filled with ultrapure water. This step dips the capillary in water to protect against sample carryover. Change the rinse water vials if they are contaminated.

4. Separation step: $20 \mathrm{~min}$ from gel buffer vial to gel buffer vial (Gel-S vial for separation). The applied voltage should be $30 \mathrm{kV}$, with REVERSED polarity (anode at the detection side) with 0.17 min ramp time. 


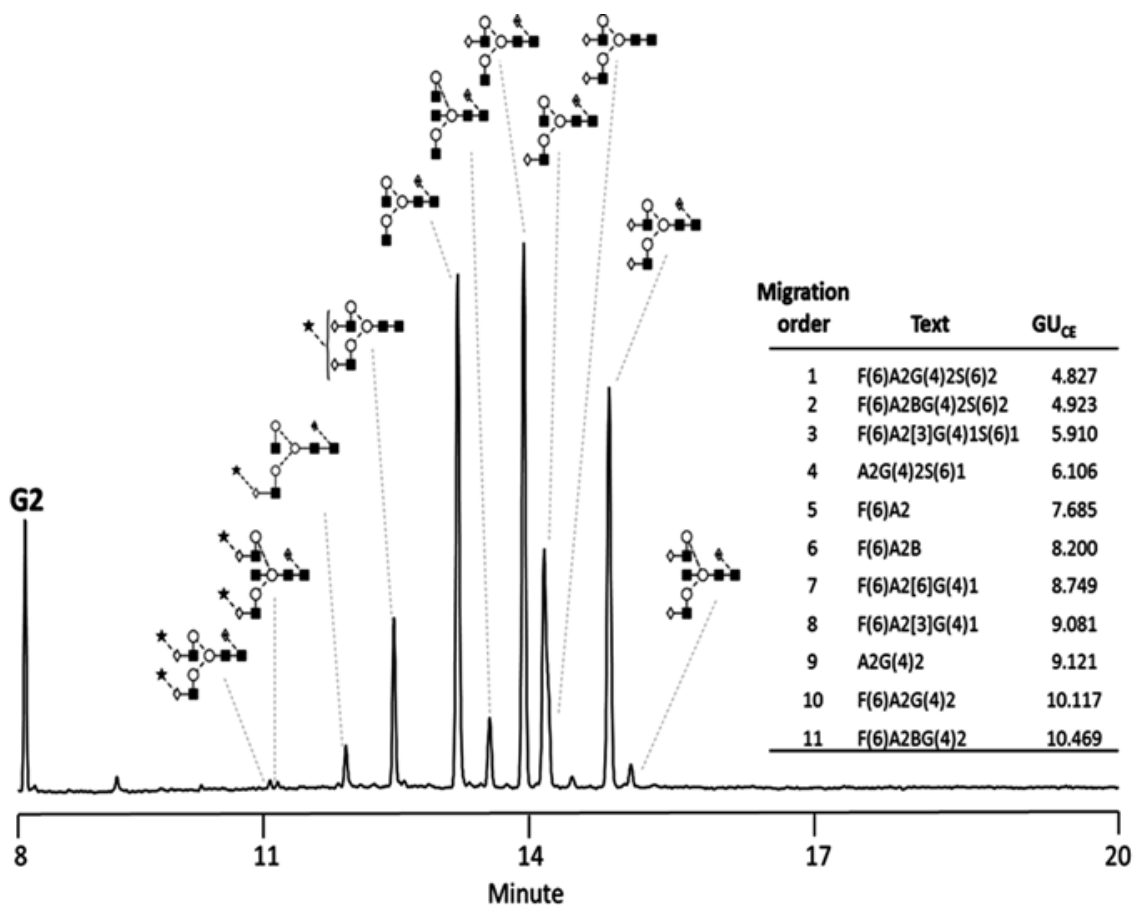

Fig. 2 High-resolution capillary electrophoresis profiling of IgG N-glycans. Conditions: capillary, N-CHO neutralcoated capillary (effective length, $50 \mathrm{~cm}$; total length, $60 \mathrm{~cm}$ ); separation buffer, $\mathrm{N}-\mathrm{CHO}$ carbohydrate separation buffer; applied electric field, $500 \mathrm{~V} / \mathrm{cm}$; separation temperature, $25^{\circ} \mathrm{C}$; pressure injection, $6.89 \mathrm{kPa}$ for $5 \mathrm{~s}$. The different glycans have been represented with cartoons based on the Oxford symbol notation with embedded linkage information [11]

3.7.3 Performing the Rapid CE-LIFAnalysis for High-Throughput Screening
5. Autozero at $1.0 \mathrm{~min}$.

6. End at $20.0 \mathrm{~min}$.

7. An example of a high-resolution CE-LIF analysis of APTSlabeled IgG N-glycans performed on $50 \mathrm{~cm}$ separation length is shown in Fig. 2 with the corresponding glycan structures of the peaks.

1. Rinse the capillary with buffer for $3 \mathrm{~min}$ at $30 \mathrm{psi}$ from gel buffer (Gel-R vial for rinse) vial to waste vial.

2. Inject the sample at 0.5 psi for $5 \mathrm{~s}$ from sample vial to buffer vial (Gel-S vial for separation). When injecting from the $10 \mathrm{~cm}$ effective length side of the capillary, make sure that the tray layout has changed accordingly.

3. Wait for $0.2 \mathrm{~min}$ with vials filled with ultrapure water. This step dips the capillary in water to protect against sample carryover. Change the rinse water vials if they are contaminated.

4. Separation step: $5 \mathrm{~min}$ from gel buffer vial to gel buffer vial (Gel-S vial for separation). The applied voltage should be $30 \mathrm{kV}$, with NORMAL polarity (cathode at the detection side) with 0.17 min ramp time. 


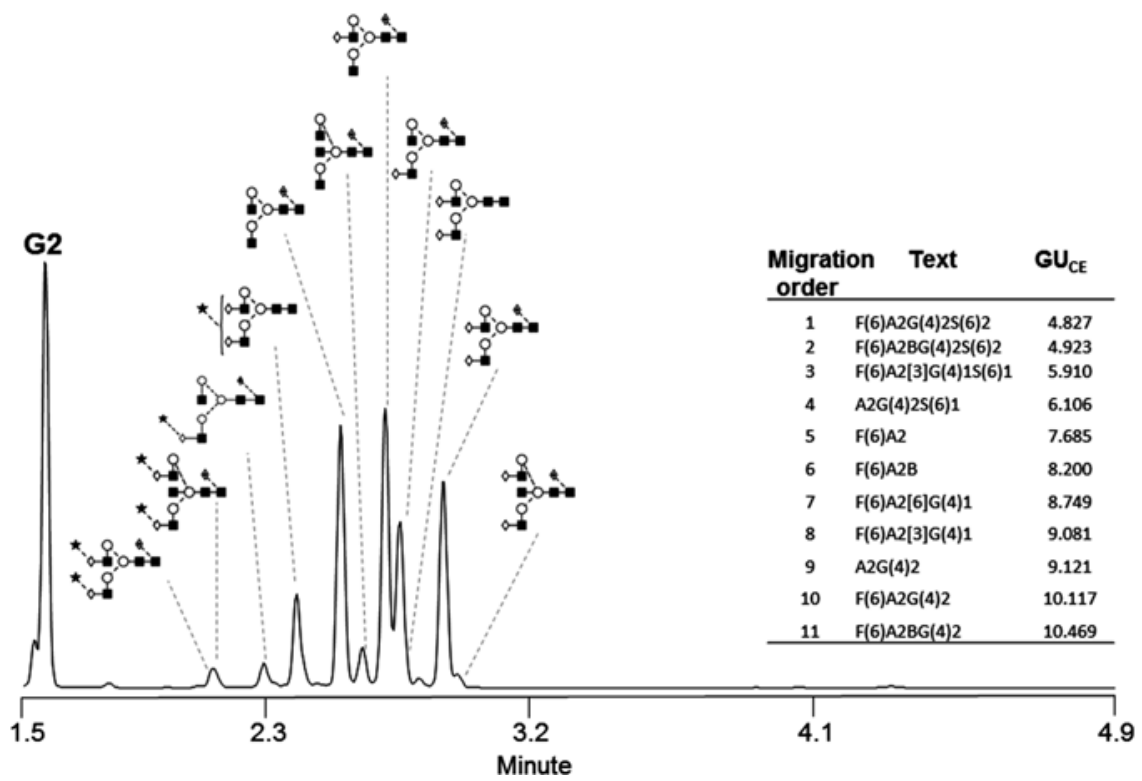

Fig. 3 Rapid capillary electrophoresis profiling of IgG N-glycans. Conditions: same as in Fig. 2 with the effective separation length of $10 \mathrm{~cm}$

5. Autozero at $1.0 \mathrm{~min}$.

6. End at $5.0 \mathrm{~min}$.

7. An example of a rapid CE-LIF analysis of APTS-labeled IgG $\mathrm{N}$-glycans performed on $10 \mathrm{~cm}$ separation length is shown in Fig. 3 with the corresponding glycan structures of the peaks.

\section{Notes}

1. If the sample concentration is less than $2 \mathrm{mg} / \mathrm{mL}$, preconcentrate before starting the procedure.

2. Make sure that all the liquid passed through the membrane after the last step. If not, spin it again.

3. Never use higher $g$-forces for the inverted cartridge as it can destroy the membrane.

4. When vortexing, always hold the filtration device vertically.

5. Do not discard the flow through because it contains the released $\mathrm{N}$-glycans.

6. Always work with $\mathrm{NaBH}_{3} \mathrm{CN}$ in the fume hood!

7. Always prepare fresh acetonitrile solutions. 


\section{Acknowledgments}

The authors acknowledge the kind support of Beckman Coulter, Inc., PhyNexus, Inc., and ProZyme, Inc. This work was supported by the Fulbright Research Scholarship \#I-174444, the OTKA Grant \#K-81839 of the Hungarian Research Council, the MTA-PE Translational Glycomics program (\#97101) of the Hungarian Academy of Sciences, the P301-11-2055 of the Grant Agency of the Czech Republic, and IACH institutional research plan RVO: 68081715 .

\section{References}

1. Marino K et al (2010) A systematic approach to protein glycosylation analysis: a path through the maze. Nat Chem Biol 6(10): 713-723

2. Brinks V et al (2011) Quality of original and biosimilar epoetin products. Pharm Res 28(2):386-393

3. Chung CH et al (2008) Cetuximab-induced anaphylaxis and $\mathrm{IgE}$ specific for galactosealpha-1,3-galactose. N Engl J Med 358(11): 1109-1117

4. Endo T (2009) New era of glycoscience: intrinsic and extrinsic functions performed by glycans. Foreword. Biol Pharm Bull 32(5): 765-766

5. Jelkmann W (2010) Biosimilar epoetins and other "follow-on" biologics: update on the European experiences. Am J Hematol 85(10): 771-780
6. Kamoda S, Kakehi K (2006) Capillary electrophoresis for the analysis of glycoprotein pharmaceuticals. Electrophoresis 27(12): 2495-2504

7. Guttman A (1996) Capillary gel electrophoresis. Methods Mol Biol 52:157-169

8. Oefner PJ, Chiesa C (1994) Capillary electrophoresis of carbohydrates. Glycobiology 4(4):397-412

9. Volpi N, Maccari F, Linhardt RJ (2008) Capillary electrophoresis of complex natural polysaccharides. Electrophoresis 29(15):3095-3106

10. Laroy W, Contreras R, Callewaert N (2006) Glycome mapping on DNA sequencing equipment. Nat Protoc 1(1):397-405

11. Harvey DJ et al (2009) Proposal for a standard system for drawing structural diagrams of $\mathrm{N}$ and $\mathrm{O}$-linked carbohydrates and related compounds. Proteomics 9(15):3796-3801 